\title{
逆流防止弁形成食道胃吻合術の遠隔成績
}

\author{
東北労災病院外科 \\ 今岡 洋一 松代 隆 山本 協二 \\ 徳村 弘実針生 常郎
}

近位側胃切除後の逆流性食道炎を防止寸るため, 逆流防止升形成食道胃吻合術を考案し, 施行後長 期経過例に括ける遠隔成績を中心に検討した. 対象とした 34 例を 3 年以上を経過した A 群(16例), 経 過 3 年末満の B 群 (18例) の 2 群に分けて検討した。長期経過後強い胸やけを訴えていたのは 2 例の みで, ともに 3 年末満経過の B 群の症例であった。 3 年以上経過した症例では愁訴は軽度であった。 体重の回復, 食事回数などでは経過年数の長い A 群で良好であった. 内視鏡所見から食道炎と思われ た症例は 2 例であったが，これらではいずれる防止弁が吻合口から離れて位置していた，胃透視上防 止弁の大ささを測定すると， $3 \sim 4$ 年でも術直後の 80 ～ $85 \%$ 程度であり，長期間を経過しても弁の萎 縮は起こらず，有効に機能しているすのと思われた，本術式は，逆流性食道炎という近位側胃切除術 のもっとも困難な合併症を防止する簡便かつ有用な術式と考えられた。

Key words : proximal gastrectomy, valvulofundoplastic esophagogastrostomy, reflux esophagitis

はじめに

胃全摘術，近位側胃切除術などで，下部食道，噴門 に手術操作が加わることにより逆流防止機構が失われ て起こる逆流性食道炎は臨床上極めて重要な問題とな る. 近位側霄切除術兼食道胃吻合は, 幽門側胃が温存 され，食䬣が十二指腸を通過する点で，生理的にもき わめて有利な術式であるが, 逆流性食道炎の出現頻度 が24〜76\%1) と) と㴗の再建法にくらべて高いとされ る.そのために，本法を避けて，他の再建法 ${ }^{2) 3(5) 6)}$ が用 いられる傾向があった，われわれは，この近位側胃切 除後の逆流性食道炎を防止する目的で, 簡便かつ有効 な逆流防止弁形成食胃吻合術を考案し，1979年以降約 60例に施行して良好な結果を得てきている778). 今回 は, 本術式施行後長期経過例における. 術後遠隔調查 結果拉よび各種形態学的検索結果を中心に, 本術式の 有用性について検討したので報告する。

\section{I. 術式の概要}

皮膚切開は上腹部正中切開とし，通常の近位側胃切 除之同様に右胃動脈, 右胃大網動脈を温存して, 大網, 小網の処理を行う. 胃の切離予定線上で漿膜笳層のみ をメスにて切離する。この際, 胃大彎側切離端が一辺

<1990年10月11日受理>別刷請求先：今岡 洋一

干981 仙台市青葉区台原 $4-3-21$

東北労災病院外科
2.5 3cm の三角形に残るようにする.その後, 切離予 定線の両端を引っ張り直線とし, 胃縫合器を用いて粘 膜のみを切離する。この操作で大察側が三角形に突出 した残胃ができる。この三角形の部分を取り囲をよう に巾着縫合して三角部を胃内に埋没させ，逆流防止弁 とする。弁が触れる高さの胃前壁において, 食道胃端 側吻合を行ら。この操作により，食慨が通過する場合 を除いて，吻合口は後方より弁によって閉鎖され，胃 内容の逆流が抑止される。吻合終了後, さきに埋没し た部をつり上げるように食道の左後方に 1 ないし 2 針 固定し，新しい胃底部をつくる.ドレナージとして以 前は幽門形成術を, 最近は幽門筋切開を行っている (Fig. 1).

\section{II. 検索対象と方法}

検索対象は，1980年より1986年むでの 7 年間に本術 式を行った 51 例のち, 直接死亡 1 例, 退院後死亡 10 例 を除いて, 術後 1 年以上を経過し, 追跡調査を行いえ た34例である. 退院後死亡の 10 例のうち，9例は ss 以 上に浸潤する進行癌で, 原病死 8 例, 他病死 1 例で, 10 か月から 4 年 6 か月で死亡した。残りの 1 例の早期 癌症例は 6 年 5 か月後, 残胃癌にて死亡した。 今回対 象とした34例は，胃癌26例（うち sm 以下の早期癌は $\mathrm{m} 7$ 例, sm 6 例の計 13 例, $\mathrm{pm} 8$ 例, ss 以上 5 例, $\mathrm{n}_{0}$ 22 例, $\mathrm{n}_{1} 2$ 例, $\mathrm{n}_{2} 2$ 例 $)^{10)}$, 胃粘膜下腫瘍 6 例, 胃潰璂 1 例, その他 1 例（膵索胞に対する手術の際, 近位側 
Fig. 1 a) Formation of an antireflux valve. b) Esophagogastrectomy at the anterior wall of the stomach. c) Formation of a new gastric fundus. d) Pyloromyotomy is carried out.

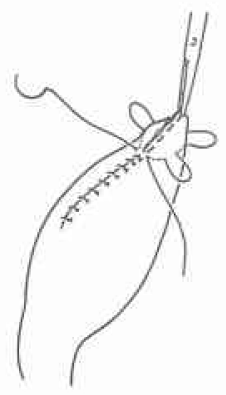

a)

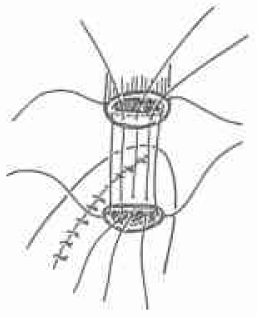

b)

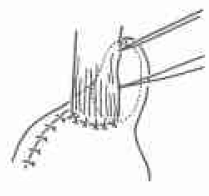

c)

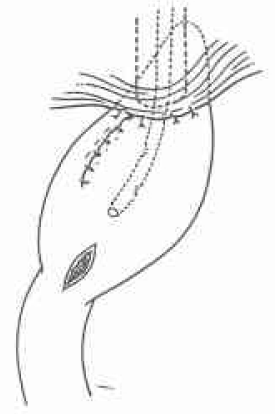

d)

Table 1 Review of patients undergone valvulofundoplastic esophagogastrostomy

\begin{tabular}{lccc}
\hline Dismasia & Group A & Group B & Total \\
\hline Gastric cancer & 12 & 14 & 26 \\
$\begin{array}{l}\text { Submucosal tumor } \\
\text { of stomach }\end{array}$ & 3 & 3 & 6 \\
$\begin{array}{l}\text { Gastic ulcer } \\
\text { Others }\end{array}$ & 1 & 0 & 1 \\
\hline Totel & 0 & 1 & 1 \\
\hline & 6 & 18 & 34 \\
\hline
\end{tabular}

胃切除を施行) であった（Table 1)。これらのうち, 術後 3 年以上を経過した 16 例を A 群, 1 ないし 3 年末 満経過した18例を B 群，の 2 群に分け，アンケート調 査により長期経過後愁訴を検討するとともに, 胃 X 線 検查, 内視鏡検査などによる逆流防止弁の形状の変化 などにつき比較検討した。 また，長期経過後の血液生 化学所見を胃全摘例の々れと比較した。な技，有意差 の検定にはStudent's t 検定を用いた。

$$
\text { III. 結 果 }
$$

1) アンケート結果

長期経過後の愁訴をみると, 胸やけがつねにみられ たのは B 群の 2 例のみであり，A群では 3 例がときど き胸やけがあるとしていたのみでこれ以外に胸やけの 訴えはなかった．A群で胸やけを訴えた 3 例のうち 2 例は初期の症例で, 退院時から同様の訴觉がみられて いた。これ以外の愁訴でも，B群ではつか感, げっ ぷが各 2 例に, 胃のもたれ感が 1 例で常にみられてい たのに対し、A 群ではいずれる軽度にとどまってお

Table 2 Complaints in follow-up duration

\begin{tabular}{|c|c|c|c|c|}
\hline & & Severe & & Mild \\
\hline & Group & Group B & Group & Group B \\
\hline Heartburn & 0 & 2 & 3 & 3 \\
\hline Oysphagia & 0 & 2 & 4 & 5 \\
\hline Belching & 0 & 2 & 2 & 4 \\
\hline Hiccup & 0 & 0 & 2 & 2 \\
\hline Nausea & 0 & 0 & 1 & 5 \\
\hline Heaviness & 0 & 1 & 2 & 2 \\
\hline Fullness & 0 & 0 & 4 & 5 \\
\hline
\end{tabular}

Table 3 Changes in body weight and times of meals in a day

\begin{tabular}{c|ccc|ccc}
\hline & \multicolumn{3}{|c|}{ Body weight } & \multicolumn{3}{c}{ Times of meals in a day } \\
\cline { 2 - 7 } & gain unchanged & los $\$$ & 3 & 4 & $5 \sim$ \\
\hline $\begin{array}{c}G \text { Goup A } \\
(n=16)\end{array}$ & $T(2)$ & 4 & 5 & 14 & 1 & 1 \\
$\begin{array}{c}G \text { Goup B } \\
(n=18)\end{array}$ & $5(2)$ & 2 & 11 & 13 & 3 & 2 \\
\hline Total & $12(4)$ & 6 & 16 & 27 & 4 & 3 \\
\hline
\end{tabular}

り, 術後経過年数の長い A 群で B 群に比べて愁訴が 軽度である傾向を認めた（Table 2).

長期経過後の体重を退院時と比較すると, 増加がる られたのは A 群で 7 例, B 群で 5 例と A 群でやや体 重の回復が良好である傾向を認めた。しかし術前値ま で回復していたのは A 群, B 群ともに 2 例のみで両群 間に大きな差はなかった。長期経過後に打ける食事回 数の変動では, A 群では16例中14例とほとんどの症例 が 1 日 3 回に戻っていたのに対し，B群では 1 日 4 な いし 5 回と分割摂取のままとしている症例がやや多 かった (Table 3).

以上より, 愁訴の内容や，体重の変化拈上び食事回 
Table 4 Development of signs of gastroesophageal reflux in posoerative period and follow-up duration as studied by upper GI series or scintigram

\begin{tabular}{|c|c|c|c|c|}
\hline & \multicolumn{2}{|c|}{$\operatorname{taflax} x(+)$} & \multicolumn{2}{|c|}{ rotiux $i-1$} \\
\hline & $\begin{array}{c}\text { Group A } \\
(n=16)\end{array}$ & $\begin{array}{c}\text { Group B } \\
(n=18)\end{array}$ & $\begin{array}{c}\text { Group } A \\
{[n=t \theta]}\end{array}$ & $\begin{array}{l}\text { Araso } \\
\text { [n.6187] }\end{array}$ \\
\hline Poatope & 3 & o & 13 & +8 \\
\hline Follow-ry & 3 & 3 & 12 & 11 \\
\hline
\end{tabular}

Fig. 2 Percent change in size of the antireflux valve

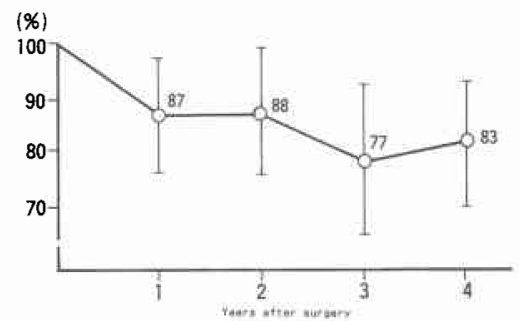

数の変化などは，経過年数の長い $\mathrm{A}$ 群でいずれも良好 となっており, 長期経過後の回復は良好であると思わ れた。

2) 逆流の有無

食道胃透視ないし99m-テクネシウムパーテクネ テートをもらいたシンチグラムによる逆流の有無を術 後および長期経過後とで比較した，術後（入院中の 3 週から 2 か月）の検索で逆流を認めたのは34例中 A 群 3 例のみであったのに対し，長期経過後ではA 群 3 例, $\mathrm{B}$ 群 3 例で検査上の逆流を認めた。これら 6 例の らち内視鏡を施行した 4 例（A 群 2 例, B 群 2 例) 中 3 例では弁が吻合口より離れて位置し, 有効に機能し ていないすのと思われた。 またこれらのうら2例（と もにB 群) では食道下部に発赤, びらんが著明で, 食 道炎の所見であった（Table 4).

3）防止弁の変化

食道胃透視では，逆流の有無に加えて弁の大きさを 測定し，弁の萎縮などの有無につき検討した。長期経 過後の外径に対する百分率で示した。1 年ないし 2 年 では約 $90 \%$ 程で， 3 年ないし 4 年後に $80 \%$ 前後となっ ており大きな変動はないるのと思われた（Fig. 2).

\section{4) 内視鏡所見}

術後 3 年以上経過した A 群での長期経過後食道内 視鏡所見では，高度発赤，びらんなど明らかな食道资
Table 5 Effects of proximal gastrectomy and total gastrectomy on hematopoietic parameters

\begin{tabular}{|c|c|c|c|c|}
\hline & $\begin{array}{l}\text { R B C } \\
\left(\times 10^{4}\right)\end{array}$ & $\begin{array}{l}\mathrm{H} \mathrm{b} \\
(\mathrm{g} / \mathrm{dL})\end{array}$ & $\begin{array}{l}M C V \\
\left(\mu \pi^{2}\right)\end{array}$ & $\begin{array}{l}\text { Serum Fe } \\
(\mu \mathrm{g} / \mathrm{d} l)\end{array}$ \\
\hline $\begin{array}{l}\text { Proximal } \\
(n=26)\end{array}$ & $388=41$ & $12.5 \pm 1.2$ & $96,4 \pm 5.5$ & $120 \pm 43$ \\
\hline $\begin{array}{l}\text { Total } \\
\qquad(n=23)\end{array}$ & $365 \pm 59$ & $17-1=1.4$ & $98.4=23.7$ & $102 \pm 37$ \\
\hline
\end{tabular}

Mean \pm SD

を示す所見は見られなかった。軽度発赤を認めた 2 例 は，ともに軽い胸やけを訴えていた，B群では，2例 に潰瘍形成を伴う食道炎の所見を認めた。 その他の症 例はいずれも汪ぼ正常の粘膜像であった。 また作成し た防止弁を観察しても，萎縮などの所見は認められな かった。

5）血液生化学検查所見

長期経過後遠隔時の赤血球数, ヘモグロビン (Hb) 濃度, 平均赤血球容積 (MCV), 血清鉄などを同時期 に行った胃全摘術群と比較した，近位側群の経過年数 は 1 年から 4 年 6 か月, 平均 3 年10か月で, 胃全摘術 群では 1 年から 11 年, 平均 2 年 10 か月である。近位側 群では, 全摘群にくらべて, 赤血球数, $\mathrm{Hb}$ 濃度, $\mathrm{MCV}$ にはほとんど差はなく，ともに大球性負血の像を示し ていた。血清鉄では近位側群が全摘群に比べて高値で あった（Table 5).

\section{考案}

近位側胃切除術が行われるのは高位胃潰瘍を主とし た胃良性疾患および噴門部癌である，良性疾患ではで きる限り機能を温存するために本例式の適応例は多い

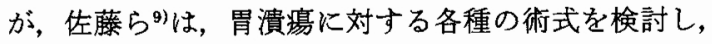
近位側胃切除術で全摘術にくらべ, 術後の消化器症状, 手術に対する満足度などで劣っていることが多いと述 ベ, 渡部 $5^{3)}$, 逆流性食道炎の発生を防止すべく, 空 腸挿入による再建を行って食道炎の発生率が低下し た，と報告している，噴門部癌に対しては胃全摘術， 近位側胃切除術のいずれかが選択されるがこの場合に は, いらまでもなく, 癌に対する根治性が最優先され る. 諸家の近位側胃切除術の胃癌取扱い規約 ${ }^{10)}$ にのっ とった適応を見ると, 井口ら²は，Cに限局型, あるい は浸潤型であっても漿膜浸潤のないものとし，このよ うな症例では近位側胃切除術では郭清が不十分となる $4 \mathrm{~d} ， 5 ， 6$ のソパ節転移はきわめてまれてあり，根 治性は十分保たれると述べて打り，ほぼ同様の適応基 準を用いる施設5111) 13)が多いように思われる。これに 対し, 丸山ら ${ }^{14)}$, 三隅 ${ }^{15)}$ は, 近位側胃切除術では根治 
性に劣ることが多く，全摘術を原則とすべきことをす すめている，自験例では，退院後に死亡していた10例 中 9 例はss 以上まで浸潤した進行胃癌で，8例は原病 死であった。しかし，第89回日本外科学会総会で発表 したごとく, 本法を含め, 近位側胃切除を行ったC, $\mathrm{CM}, \mathrm{MC}$ 領域癌でも $\mathrm{m}, \mathrm{sm}, \mathrm{pm}$ 癌68例の累積生存率 は94.9\%であった，最近は本法の適応をこのへんにお いている.

根治性に差がないとした場合の胃全摘術と近位側胃 切除術の選択について, 水本ら ${ }^{161}$ はこれらの両術式に 扣ける血清ガストリン，セクレチン動態を検討し，膵 外分泌，消化吸収の両面で近位側胃切除術が胃全摘術 より有利であるとのべている。また，小沢ら ${ }^{11}$ る同様に 両術式に打いて術後愁訴, 血液生化学検査では概衫近 位側胃切除術が優っていたと報告し本術式の適応を抎 大すべきとしている，自験例でも，貧血の程度では両 術式間に差はなかったが，血清鉄では近位側胃切除群 が有意に高值であり，鉄代謝の面で有利であるものと 思われた。

近位側胃切除術を行う場合の再建法としては, 残胃 の大きさが十分得られるならば，食道胃吻合が望まし いことは当然である。しかし，いったん逆流をきたし た場合には容易に食道粘膜が胆汁にさらされ，食道炎 もむしろ重篤な経過をたどることが多い17)。この欠点 を克服するべくさなざなな工夫が試みられてきたが， いずれも手技の煩雑さ，あるいは逆流防止が不完全な ために一般的とはなりえなかったように思われる，著 者らの考案した逆流防止弁形成食道胃吻合術の要点 は，三角形に残した大彎側切離端を埋没させることに より逆流防止弁を作ることに加党, 吻合部直上の食道 左側にこの部をつり上げるように固定することによっ て人工胃底部を作ることにある。すなわち，逆流防止 升により，不十分となりがちな食道昇圧帯を強化し， さらに弁自体に上る食道吻合口の閉鎖をむ期待するる のである。すでに報告した通り7), 術後の胃透視, 食道 胃シンチグラムあるいは引き抜き法による食道内圧測 定では, 逆流防止弁が有效に作用して逆流子少なく, また食道昇圧帯の形成も十分であるとの結果を党てい る.

幽門形成術の付加について, 小野ら ${ }^{18}$ は, 幽門形成に よって同部の機能を廃絶させるのは幽門部掞よび括約 筋を温存してダンピング症候群, 消化障害, 貧血を防 ごうといら本術式の治療的意義に反するものであり， 切除量が大きくて, 残胃の小さい場合にのみ幽門形成
を行らべきであるとし，片柳ららも添涪同様の理由で， 残胃の大きさが $1 / 3$ 以上ある場合は付加する必要はな いとしている。著者らも，以前は逆流防止の観点から 幽門形成を行っていたが，最近は，ダンピング症候群 の防止のため，幽門筋切開にとどめることを原則とし ている.

次に問題となるのは上記のような逆流防止升の働き が長期間にわたって持続しうるのかどらかという点で ある。この点を明らかにするため，今回は 1 年以上の 経過例を対象として, 主に長期経過例における成績を 中心として検討を行った。

まず長期経過後の愁訴では, 高度の食道炎を思わせ る胸やけ, 吐き気などの症状は術後 3 年末満の群で多 く，長期経過例ではむしろ少なくなる傾向が見られた。 その他のものでも同様の傾向であり，長期の経過によ り愁訴は軽減している傾向を認めた，有愁訴例では内 視鏡所見で食道炎を思わせる発赤, ぴらんなどの所見 を認めた。福元 ${ }^{199}$ は, 臨床症状と内視鏡所見とはかなら ずしも一致しないとし，内視鏡所見の読み方による相 違，愁訴が間欠的である，症状については感じる側の 差がある，などの理由をあげている，自験例において は症状の強いものでは内視鏡的にも高度の食道炎がみ られ，それ主どの解離はみられなかった。 3 年以上経 過の A 群では, 明らかな食道炎様の所見を示するのは なく，軽度発赤を 2 例に認めたのみであった。

胃透視上で防止弁の外径を測定し経時的にその変動 を見ると, 術直後と比較して 1 年ないし 2 年後に約 90\%汪どに縮小寸るが，3ないし 4 年経過しても $80 \%$ 前後と大きな変動はなく, 形成した弁の萎縮は長期間 経過しても起こらないものと思われた。内視鏡的に観 察しても同様であり，著明な萎縮などの所見の見られ た例は1例もなく，いったん形成された弁には大きな 変化は起こらず，有効に作動し続けると思われた。最 後に本例式の要点について触れる，防止弁については 再三述べてきたようにその效果は十分に持続的である と思われる。しかし，食道炎の見られた症例のうち一 部の胃底部の形成が不十分な症例では，防止弁が吻合 ロから離れて存在する形となっており，弁そのものの 形状に問題がなくとも, 結果的に逆流防止が不十分々 なっていた。この点からみても，逆流防止の働きを保 持する上で, 防止弁の形成に加光，胃底部の形成を適 切に行らことが重要である点を強調したい。

$$
\text { 文献 }
$$

1）林 佰男, 遠藤光夫, 吉田 操隹加：逆流性食道炎 
の臨床的検討. 手術 $33: 1233-1239,1979$

2）井口絜, 中村輝久：術後逆流性食道炎とその対 策一噴門部切除一.臨外 $32: 37-43,1977$

3）渡部洋三, 巾 尊宣, 城所 仂ほか：噴門側胃切除 術に招汀る逆流防止術式の検討. 外科 46 : 597-602, 1984

4）三浦敏夫, 羅向, 胜倉 薰住か：上部胃癌手術 術後愁訴の検討一術式の変遷と逆流性食道炎を中 心に一.外科 $43: 257-265,1981$

5）片柳照雄, 粟根康行, 北村正次ほか：上部胃癌に対 する噴門側切除, 空腸間置術, とくに術式と適応に ついて.手術 35:123-127, 1981

6) Lenzi V, Fromm D: Preservation of the distal part of the stomach by esophagoantral jejunal interposition. Surg Gynecol Obstet 168 : $175-176,1989$

7）松代隆,針生常郎, 長嶋英幸ほか: 逆流防止弁形 成食道胃吻合術. 日消外会誌 $16: 2053-2059$, 1983

8) Matsushiro $T$, Hariu $T$, Nagashima $H$ et al: Valuvuloplasty plus fundoplasty to prevent esophageal regurgitation in esophagogastros. tomy after proximal gastrectomy. Am J Surg $152: 314-319,1986$

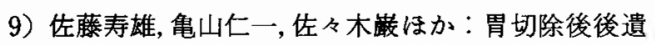
症, 特に術後愁訴からみた各種胃切除術式の検討. 消外 3:1663-1669, 1980

10）胃癌研究会編：胃癌取扱い規約. 改訂第11版, 金原
出版, 東京, 1985

11）小澤正則, 杉山 譲, 三上泰徳ほか：胃上部癌に対 する噴門側胃切除術の適応について一胃全摘術と の比較一. 日消外会誌 $18: 655-662,1985$

12）鈴木 力, 武藤輝一, 佐々木公一ほか：上部胃癌に 対する根治手術一胃全摘術および噴門側胃切除術 の適応と選択. 日消外会誌 $20: 947-950,1987$

13）太田恵一朗, 西 満正, 中島聰總：上部胃噴門癌の 手術方針, とくに噴門側切除の適応基準について. 日消外会誌 $20: 956-960,1987$

14）丸山圭一, 北岡久三, 平田克治注か：噴門部癌に対 寸る手術術式の選択，根治性加占。消外 6： 1425-1431, 1983

15）三隅厚信, 赤木正信, 馬場憲一郎ほか：噴門癌の外 科的治療における問題点一近側胃切除々胃全摘術 の比較一. 日消外会誌 $17: 6-14,1984$

16) 水本 清, 西村興严, 古賀成昌：近位胃切除, 胃全 摘術後の血清 gastrin, secretin 動態の消化管 - 膵 への trophic action. 日外会誌 $86: 1165-1168$, 1985

17）熊谷義也, 関惇, 佐々木哲次ほか：逆流性食道 炎の病態生理.外科 $35: 494-502,1973$

18）小野慶一, 鳴海裕行, 渡辺襄注：横隔膜下胃底 部切除術之幽門部括的筋機能.外科治療 11 : $127-144,1964$

19）福元俊孝：術後逆流性食道炎に関する臨床病理学 的研究. 医研究 $52: 328-356,1982$

\title{
The Long Term Results of Esophagogastrostomy with Valvulofundoplasty
}

\author{
Youichi Imaoka, Takashi Matsushio, Kyoji Yamamoto, Hiromi Tokumura and Tsuneo Hariu \\ Department of Surgery, Tohoku Rosai Hospital
}

The long-term results of valvulofundoplastic esophagogastrostomy to prevent reflux esophagitis after proximal gastrectomy were evaluated. Thirty-four patients were divided into two groups, 18 three years or more after the operation (group A) and 18 less than three years after the operation (group B). Severe heartburn was seen in two patients of group B, in whom reflux esophagitis was seen endoscopically and the antireflux valve was apart from the anastomotic stoma. Patients in group A had only mild complaints. Group A patients also recover better in terms of body weight and dietary habit than those in group B. After $3 \sim 4$ years, the size of the antireflux valve was reduced to about $80 \sim 85 \%$ of those measured in the postoperative period. Thus, it seems that an antireflux valve remains effective even after long interval. We think this procedure is easy and yet effective enough to prevent complications of poximal gastrectomy, such as reflux esophagitis.

Reprint requests: Youichi Imaoka Department of Surgery, Tohoku Rosai Hospital 4-3-21 Dainohara, Aoba-ku, Sendai, 981 JAPAN 